\title{
Graduate Student Audit Project
}

Michael D. Akers, (Email: Michael.Akers@marquette.edu), Marquette University Jodi L. Bellovary, (Email: Jodi.Bellovary@marquette.edu), Marquette University

\begin{abstract}
This paper discusses Marquette University's graduate student audit project, designed to enhance student learning and retention of auditing procedures and concepts learned in the classroom.
\end{abstract}

\section{INTRODUCTION}

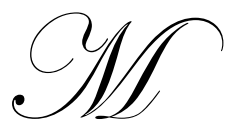

arquette University currently has one audit course that serves both undergraduate and graduate students. Course objectives include providing students with an overview of the audit process, preparing students for entry-level auditing positions and providing opportunities for students to demonstrate communication skills. These objectives are addressed through student participation in an audit of a Marquette University department. The graduate audit project enhances student learning, and simultaneously provides a service to the University. The purpose of this paper is to discuss the graduate audit project of the course.

The paper first outlines the objectives of the graduate audit project and initial considerations for project implementation. Next, details of the graduate audit project and grading are discussed. Examples of documentation from the engagement, such as the planning memo and audit report are provided. The paper concludes with observations from students, the professor and administration.

\section{OBJECTIVES OF THE GRADUATE AUDIT PROJECT}

There are two main objectives of the project. The first and primary objective of the graduate audit project is to enhance student learning. Knowledge and, more importantly, retention of auditing procedures and concepts learned in the classroom are crucial for students' future success in the auditing profession. The project provides students with an opportunity to apply auditing procedures, which increases retention. Whether or not they plan to become auditors, active participation in an audit provides students with valid, real-world experiences that prepare them for postgraduation employment. After participating in the project, one student indicated that "it will be much easier and less intimidating now to go out and perform an audit interview in practice." Another student commented, "I had always experienced audits from the other side, so it was beneficial to see how things go from the auditor's perspective. It is easier to see that they aren't just trying to be annoying; they really do have a purpose."

The second objective of the graduate audit project is to provide a service to the institution. Service is fundamental at Marquette University, from the University level to the Department of Accounting. As written in the University's Mission Statement, "our mission...is the search for truth, the discovery and sharing of knowledge, the fostering of personal and professional excellence, the promotion of a life of faith, and the development of leadership expressed in service to others." As stated in the College of Business Administration's Mission Statement, the College's "goal is to foster a community of scholars committed to improvement and collaboration, and to enhance interaction with business and service organizations...[in order to] create a superior environment for learning and development of our students." The Department of Accounting's mission emphasizes leadership and service, with the goal being to prepare students to be responsible, competent and ethical leaders. Participation in the audit adds to the development of students' professional excellence and, at the same time, provides a service to the institution.

\section{INITIAL CONSIDERATIONS/ISSUES}

There are six issues that must be considered when coordinating the graduate audit project. The project may be completed either in conjunction with the institution's internal auditor/audit department, or under the guidance of 
A second consideration is the willingness of the professor to coordinate the project. The professor sets up and attends an initial meeting of the students with the internal auditor/outside consultant. At Marquette University, this meeting was held outside of the scheduled class time. For the project duration, the students work directly with the internal auditor/outside consultant and the department being audited. While the professor does not directly supervise the project, he or she is responsible for maintaining communication with the internal auditor/outside consultant in order to monitor the project's progress/status.

The university must be comfortable with the students reviewing confidential information. As auditors, the students will have access to sensitive information. It is important that the students sign a confidentiality agreement (see Exhibit 1) and be made aware of the importance of not disclosing sensitive information to unauthorized parties.

The treatment of the student auditors is another important consideration. Will the students be treated as professionals, or as students doing a project for class? The students should be introduced to department personnel as representatives of internal audit, not as students doing a project. The students at Marquette University have been well received and treated as professional auditors during the project.

The availability of university personnel and the schedules of the internal auditor/outside consultant and students must be taken into consideration. Ideally, the project should start early in the semester to allow sufficient time to complete the audit before the end of the semester. The internal auditor/outside consultant's schedule and availability impacts the timing of the audit work. Availability of university personnel (auditees) also affects the scheduling of the work.

Lastly, the proper amount of audit work for graduate credit must be planned and assigned. The actual audit work to be performed by the students is determined by the professor and the internal auditor/outside consultant.

\section{DESCRIPTION OF THE GRADUATE AUDIT PROJECT}

This section of the paper discusses the project for a semester when an outside consultant was used. To illustrate the process, the documentation of one group is provided. Names have been removed and only positions/titles are presented.

The project is announced the first day of class. The initial meeting of the students and professor with the internal auditor/outside consultant is scheduled during the first three weeks of the semester. At the initial meeting, the project objectives, expectations and timetable are provided to the students. The professor should review the specific course requirements/expectations for the project. Team structure and responsibilities are discussed, including the audit program, work structure, distribution of responsibilities, budgeting, work planning and work products. Confidentiality is stressed, and each student is required to sign the confidentiality agreement. After the initial meeting, the internal auditor/outside consultant introduces the students to the auditees at a time that is mutually convenient for all those involved.

At Marquette University, students participate in an audit from start to finish. This includes planning the engagement, developing an audit program, observing and interviewing department personnel, testing transactions, analyzing results, discussing findings with management and preparing the final audit report. At the initial meeting, students are provided an overview of the audit approach (see Exhibit 2). The overview plan gives a detailed outline of the expectations, including a time budget which breaks down by responsibility the twenty-five hours allocated to the project. From the overview plan, students develop a detailed work program. An example of the work program has not been included due to space constraints; however, the work completed is evident from the final report (Exhibit 4). Work is completed by the students according to their schedules and coordination with the auditees.

Initially, students submit a draft audit report to the internal auditor/outside consultant for review. The audit report includes a description of the department being audited; department policies and procedures; audit objectives; and testing procedures, findings and recommendations. The internal auditor/outside consultant reviews the draft audit report and provides feedback via memo (see Exhibit 3) for the students to use when preparing the final audit report 
(see Exhibit 4). In addition to the final audit report, students submit the necessary audit workpapers, a time summary (see Exhibit 5) and their final analysis/assessment of the project. All of the final audit reports are assembled in a book for presentation to the Board of Trustees. In the final analysis/assessment, students discuss the most meaningful (positive) aspects of the project, any concerns that arose during the project or about the project, and any suggestions for improvements or modifications to the project. This is not an assessment of team members, but of the project itself. The assessment is used to analyze how the students believe they benefited from the project, and to plan future projects.

The graduate audit project provides an opportunity for students to gain audit experience. By involving students from start to finish, students gain a more complete understanding of the audit process. The additional involvement with preparation of the audit program and the audit report further enhances student learning.

\section{Grading}

Grading of the graduate audit project is not based on points or a traditional grading scale. Rather, a subjective assessment, which impacts final course grades, is made as to whether students met the project objectives. Generally, performance on the audit will have a positive affect on students' grades. However, grades may be lowered if students perform poorly or below expectations (based on the professor's observations and discussions with the internal auditor/outside consultant throughout the project). Alternatively, professors who disagree with the subjective assessment could formalize the grading and assign points and/or a grade to the project.

\section{Students' Assessments}

Students have provided valuable feedback in their final analysis/assessments of the graduate audit project. The most overwhelming response has been that students believe the project is beneficial because they are able to experience an audit first hand and apply knowledge learned in the classroom. Students find it valuable to be a part of the entire audit process and to work directly with the client/department personnel. Other positive aspects of the project given by students include the opportunity to improve communication skills and gain experience conducting interviews.

An area of concern students had was that work was not reviewed until the due date, rather than periodically throughout the semester. This issue may be encountered as students move out into the workforce. During the project, students are given the opportunity to learn how to handle concerns that may arise on an audit. It is beneficial for students to be aware that problems will arise and not all engagements will go smoothly.

One suggestion for future projects was to provide feedback to the students on their performance during the audit. While qualitative feedback was provided to the instructor by the outside consultant, the internal auditor/outside consultant could complete a formal evaluation form assessing students' performance. This feedback would further enhance student learning by providing suggestions for improvement. Students also commented that they would like to know whether or not the University implemented their recommendations. In fact, Marquette University has implemented several of the project recommendations.

\section{Professor's Assessment}

The professor of the auditing course believes the project has satisfactorily met both course and project objectives. Feedback from students, the outside consultant and administration indicates all parties consider the project to be worthwhile. Students' comments indicate that the project was a valuable learning experience; and the university feels that it has received quality audit work. One of the primary benefits of the project is that the students get the opportunity to work with a professional other than the professor. Since the professor serves as a consultant to the students during the project, he/she can use this opportunity to effectively reinforce the concepts/principles discussed in class. 


\section{Administration's Assessment}

Mr. Chuck Lamb, Vice President in the Office of Finance at Marquette University, believes the project is an ideal opportunity not only to provide a teaching and learning experience, but also to meet the needs of the University. The University is receiving a valuable service. It has been able to complete far more audits than it would have, had the audits been contracted out. He says that the project has been successful and the quality of the work has been very good, as good as what the University would ordinarily receive from the outside. According to Mr. Lamb, the Board of Trustees is very much in favor of this project. He says that projects that involve cooperation between students and staff have always been well received.

Ms. Charyl Burke, Director in the Office of Risk Management and Internal Audit at Marquette University, says that administration's main question at the start of the project was how would it work? Once that question was answered, the response was positive. She agrees that the projects have been a success and would like to see them continue to build and expand. Ms. Burke believes that students from other areas of the business school can complete projects beneficial to the university as well, such as management students reviewing/writing policies and procedures.

\section{CONCLUSIONS}

Currently, the graduate audit projects are completed as part of a single audit course offered at Marquette University. The projects could be expanded and completed as part of a full-semester, stand-alone audit course, such as the course being offered at Wright State University (www.wright.edu/admin/audit/iadstudent.htm). However, it is possible for institutions to implement the project without creating a separate course. Marquette University's audit course is demanding of students, but is not over burdensome (see Exhibit 6 for an excerpt of the course syllabus).

The graduate audit project is an opportunity for students to gain audit experience and enhance classroom learning. The project is versatile and adaptable to a variety of institutions. If the institution has an internal auditor or outside consultant who is willing to work with students, and administration is supportive, the institution can have graduate students complete audits. At the same time, the institution will receive a valuable service. The use of student auditors saves the institution money spent for audit fees.

The graduate audit project has saved Marquette University enough funds that the institution has decided to hire an internal auditor. The audit projects will continue, and possibly even expand, under the direction of the internal auditor. In the future, projects may include process flowcharting, which would help to enhance students' understanding of internal controls.

We acknowledge the assistance of Vincent W. Dinan, Internal Audit Consultant to Marquette University an outside consultant hired by the institution. The first consideration is the internal auditor/outside consultant's willingness to work with students. It is critical that the internal auditor or outside consultant is cooperative in working with the students. If an outside consultant is used, the specifications of the project should be discussed and included in the request for proposal for outside services. If the outside consultant is unable or unwilling to fulfill the project specifications, he or she should not be a final candidate for the job. 


\section{EXHIBIT 1}

\section{Confidentiality Policy}

Some positions at the University will involve regular access to confidential information. It is expected that such information will not be discussed with relatives, friends, or others outside the University or in public areas of the University. Confidential information should be discussed with other employees only when necessary for the performance of the job.

In some areas, release of information is governed by specific laws. If such laws affect your position you will be advised by your supervisor.

A breach of confidentiality is subject to immediate dismissal or corrective action.

I have read and understand the above policy.

Student Signature

Supervisor Signature

Department
Date

Date

Note: For departmental records only. Do not forward to Student Employment Services.

\section{EXHIBIT 2}

\section{Overview Of The Audit Approach}

\section{Introduction}

The purpose of the Audit Plan for Graduate Students (audit plan) is to provide a vehicle to guide student auditors in the performance of fiscal and operational audits of University activities. The plan objective is to help enable student auditors to realize the experience of a complete audit in a compressed period of time. Necessarily, this means that the audit scope and objectives are limited and the assignment can be completed in the time period budgeted for completion. experience:

Student auditors should concentrate on the following in order to derive maximum benefit from the audit

- In planning the audit, the scope of the work should be tightly focused on the audit objective, and concern with extraneous issues should be avoided.

- Objectivity and precision are essential elements to the audit approach. The auditor's credibility hinges upon how the quality and objectivity of his or her work is perceived by operating management. Bias and inaccuracy have no place in a successful and credible audit. 
- Maintenance of confidentiality is an absolute requirement in the conduct of an audit. The auditor will normally examine highly sensitive documents, e.g., employment records, contractual terms and conditions, financial transactions, in the course of performing the audit. A breach of confidentiality discredits the audit and the auditor.

\section{Background And Criteria For Audit}

The auditor needs to understand and document the purpose and the process of the function(s) being examined. Moreover, he or she must understand the standards against which performance or compliance by the operating unit is measured.

The general approach to developing appropriate audit criteria is to:

- Discuss the details of functional operations with the responsible supervisor or manager, and document the discussions in the audit work-papers.

- Identify, review and document the criteria that govern the process being reviewed. Routine criteria include:
A. University policies and procedures.
B. Federal and state statutes and county/city ordinances.
C. Contracts and grant terms and conditions.
D. Administrative regulations, e.g., Code of Federal Regulations.

- The auditor should ensure that he or she understands the rules that govern the process under review. In addition, the auditor must know the process well enough to determine if supervisors and staff follow procedures that meet the requirements of applicable regulations.

\section{Develop And Execute The Audit Program}

Once the auditor has become familiar with the activity being audited, has discussed operational details with the cognizant supervisor and staff, and has developed an understanding of the criteria for process management, he or she is ready to develop the audit program. The program lays out the work steps for examining and testing transactions for the purpose of process validation.

- Describe the audit objectives. Student audits will normally concern themselves with validating management procedures through a process of transaction testing. Examples of procedures subject to such testing include: compliance reviews of University hiring procedures; fixed asset acquisitions; or perhaps accounts payable disbursements.

- Formally document the operation being reviewed. A process flow diagram is useful, but time constraints may prevent completion of such a diagram. Narrative description is an alternative; it is important however, to clearly indicate, in whatever method the auditor chooses, all review and approval sequences contained in the process.

- Select transactions for testing. The auditor must identify the audit universe (the body of transactions subject to audit), the method for sample selection, and the list of transactions to be audited. For the purposes of this exercise, a judgment sample is sufficient; however, the auditor should be aware that for large volumes of transactions, a more preferred sampling method may involve statistical random sampling techniques.

- Describe the testing procedure. Essentially, this means evaluating sample transactions against the established processing standard. That is, the auditor compares each sample transaction (what did happen) with policies, procedures or regulations established by function management (what should have happened). In the event that the sample transaction does not meet the organization's procedural requirement, then a deficiency finding should be noted.

- Once testing is completed, discuss the sampling results with the responsible operations supervisor or manager. The auditor should verify that his or her observations - based on test results - are correct. 
Significant numbers of deficiency findings may indicate a serious problem with the organization's procedures and/or supervision.

\section{Prepare The Draft Audit Report}

After transaction tests have been completed and the results discussed with the appropriate level of supervision, the auditor should prepare a draft audit report. The format selected depends in large part on the size and complexity of the audit, and the nature of the findings - not to mention the audit manager's preference. In some cases, a simple report letter is appropriate; in other circumstances, a more detailed, formal document should be developed.

The general format of the draft audit report should follow the outline set forth below.

- Audit Purpose or Objectives - Describe the reason that the audit was undertaken. Examples might include:
A. To test and validate the University's accounts payable vouchering procedures.
B. To assess the University's compliance with OMB grants administration criteria.
C. To evaluate University cash disbursement practices.

The topics listed above are simply illustrations of audit objectives. The important thing is to describe clearly and concisely why the audit was performed.

- Briefly explain the functional process the auditor examined, the organizational review and reporting relationships, the authority for the activity(s), and the University policies and procedures that guide the process.

- Describe the auditor's transaction testing procedure:
A. What did the auditor examine, and what was the purpose of the examination?
B. What was the nature and size of the transaction universe?
C. How did the auditor select the sample transactions, e.g., judgment sample, statistically random sample?
D. What attributes were included in the sampling routine?
E. What significant obstacles were encountered in completing the examination?

- Discuss the findings that resulted from the audit. It is important to concentrate on materiality, and to avoid obscuring significant issues with discussions of minor problems. Each audit finding should follow a uniform format:
A. Explain the perceived deficiency.
B. Describe the official procedural requirement.
C. Evaluate the effect of the deficiency - compare what happened with what should have happened, and describe the resulting financial or operational impact.
D. If possible, extrapolate the finding over the universe of transactions examined.

- Develop recommendations to correct the observed deficiencies. The auditor is an independent objective observer and, as such, is in a position to recommend changes in practices that can correct deficiency situations and result in more efficient and economical operations.

- Present the draft audit report to function management, and discuss proposed findings and recommendations. The auditor must be viewed by operating management as an "honest broker". The audit process should be as objective as possible; no one likes criticism, and it is important that the supervisors and managers of the function being audited have the opportunity to respond to the findings. Many times, new information surfaces during this discussion that modifies the nature of the findings, their impact, and the resulting recommendations to management. Finally, operating management should be given the opportunity to respond in writing to the audit findings, and their written comments incorporated into the final audit report. 


\section{Final Audit Report}

The final audit report contains all of the elements of the draft audit report, but modified as necessary based upon the results of the review of findings and recommendations with function management. As stated previously, management's formal written reply to the findings and recommendations are to be included in the final report. Report distribution should follow University policy in such matters.

\section{Audit Budget}

The budget for each student auditor is 25 hours (for a total of 50 hours for the audit), estimated as follows:

$\underline{\text { Task }}$

\section{Hours Budgeted}

1. Research background and audit criteria.

2. Develop the audit program.

3. Initiate and complete transaction testing.

4. Analyze test results, and formulate findings and recommendations.

Prepare draft audit report and discuss details with operating management. $\quad 3$

6. Complete and issue final audit report. 2

Total number of hours budgeted

\section{SUMMARY}

This audit plan is intended to provide helpful guidelines to student auditors for performing fiscal and operations audits of University activities. The student auditor should understand that audit work-plans are devised to meet the requirements of individual audits. Accordingly, the information contained in this document can and should be modified to meet the unique requirements of each audit undertaken.

\section{EXHIBIT 3}

\section{Consultant's Review Of Draft Audit Report}

\section{MEMORANDUM}

To: $\quad$ Student Auditor

Student Auditor

From: Internal Audit Consultant

Date: $\quad$ April 23, 2002

Subject: Golden Eagle Store Draft Audit Report - Review Comments

Copies: Accounting Professor

Director, Office of Risk Management and Internal Audit

I have reviewed the subject draft, and although I think the substance is there, you have more work to do. My comments and suggestions follow. 
Presentation and Style

1. Use the active voice whenever possible to describe your efforts. Also, mark each page of the report as "DRAFT" until you publish your final document.

Cover Page

2. The report should have a cover page with appropriate attribution. Here's a suggestion:

$\underline{\text { Title }}$

Audit performed by:

Student Auditor, Senior, Department of Accounting, Marquette University

Student Auditor, Senior, Department of Accounting, Marquette University

Under the direction of:

Director, Office of Risk Management and Internal Audit, Marquette University

Professor of Accounting, Marquette University

Internal Audit Consultant, Marquette University

Table of Contents

3. Provide a Table of Contents with sections and page numbers.

Executive Summary

4. Provide a one-page Executive Summary that briefly describes your audit objectives, what you did, what you found, and what you recommend. Remember, this is a broad overview; don't provide lots of detail here.

Introduction (Store Description)

5. Expand this section to provide information such as annual sales volume and number of full and part time staff employed by the store.

Audit Objectives

6. The objectives as stated don't communicate very well. I suggest that you expand this section with simple declarative sentences that indicate your specific objectives in performing the audit.

\section{Audit Criteria}

7. You mention Store Policies and Procedures but don't describe them. I suggest that you briefly say what they are and then discuss how you evaluated store operations relative to established criteria.

Internal Controls Testing Procedure

8. Again, it is unclear how the tasks that you have listed here tie into your audit objectives; it is also uncertain what conclusions you reached as the result of your testing. I suggest that you re-consider this area and expand the discussion. 


\section{Internal Control Findings and Recommendations}

9. The findings you present don't address the question of adverse impact. I suggest that you look at these issues in terms of situations that need to be corrected and answer the question "why".

\section{Cash Transaction Testing Procedure}

10. This section is fairly detailed, perhaps too much so. There may be an opportunity to scale back some of the detail and focus on what tests were conducted and what the results were. Make sure that you report the deficiencies you observed and, alternatively, the absence of deficiencies where none were found.

\section{Cash Transaction Findings and Recommendations}

11. This section needs more discussion. On average, how much money remains in the safe overnight? Is the safe in a secure area? Try to estimate the risks associated with the amount of money stored in the safe and not dispatched to the Bursar's Office. I'm not taking issue with this finding; we just need a better explanation of the adverse circumstance.

\section{Inventory Testing Procedure, Findings and Recommendations}

12. It is not clear how the auditors verified relief of the inventory for cash sales. If the inventory is not relieved, we probably need to comment on this issue. Similarly, the "Findings" don't provide much information as a basis for management action. Lastly, adoption of an EOQ system is one option - perhaps an expensive one. I suggest that you re-think the recommendation and add other potential solutions.

\section{Golden Eagle Store Management Comments}

13. Provide a section to report the response by store management to your findings and recommendations. 


\section{EXHIBIT 4}

\section{Final Audit Report}

Risk Management

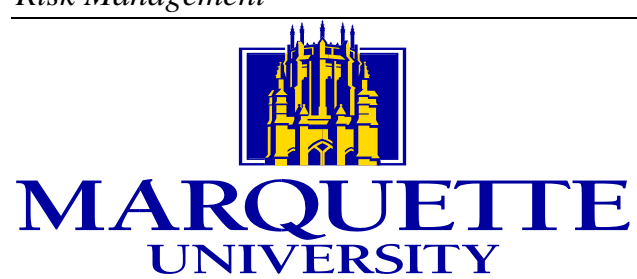

OFFICE MEMORANDUM

TO: $\quad$ Director, The Golden Eagle

Alumni Memorial Union

DATE: $\quad$ August 1, 2002

FROM: Director, Risk Management and Internal Audit

SUBJECT: Final Audit Survey - The Golden Eagle Store

Enclosed is the final audit report on the survey that was conducted in May 2002. This final report contains audit comments by management as well as the guidelines used and any findings or recommendations. You may notice slight changes in the format of this audit issued by the department from the version submitted by the student auditors at the conclusion of their audit project. Nevertheless, the management comments as well as the content of the audit have not changed.

This area may be subject for additional review in the future as part of the multi-year internal audit plan. Please feel free to forward documentation or communication on procedures that are changed in accordance with findings and comments from this survey.

We sincerely appreciate the time and assistance you and your staff spent with the graduate student auditors and our audit consultant. Please call me at 288-1552 if you have questions or additional comments.

cc: Director of Operations, Office of External Relations and Administration

East Hall, M215 P.O. Box 1881 Milwaukee, Wisconsin 53201 Telephone (414) 288-6806/7456 Fax (414) 288-6600 
Internal Audit Survey Report

Golden Eagle Store

Marquette University

May 2, 2002

Audit Performed By:

Student Auditor, Senior, Department of Accounting, Marquette University

Student Auditor, Senior, Department of Accounting, Marquette University

As Directed By:

Director, Office of Risk Management and Internal Audit, Marquette University

Professor of Accounting, Marquette University

Internal Audit Consultant, Marquette University

Table of Contents

\section{$\underline{\text { Section }}$}

I.

II.

III.

IV.

V.

VI.

VII.

VIII.

IX.

X. $\underline{\text { Title }}$

Executive Summary

Introduction - Store Description

Audit Objectives

Procedure to Gain an Understanding of Internal Controls

Internal Control Testing Procedure

Internal Control Findings and Recommendations

Cash Transaction Testing Procedure

Cash Transaction Findings and Recommendations

Inventory Testing Procedure

Inventory Findings and Recommendations

\section{$\underline{\text { Page }}$}

3

4

4

5

5

7

8

10

11

\section{Executive Summary}

Throughout February, March and April the auditors performed an operational audit of the Marquette Golden Eagle store. The general objectives of this engagement were as follows:

- Obtain an understanding of internal controls

- Perform tests of cash transactions

- Evaluate inventory procedures.

During the operational audit, the auditors evaluated selected documents, procedures and policies, in order to obtain an understanding of internal controls. The auditors performed interviews with management personnel and observed daily operations in the Golden Eagle to test internal control.

Auditors' recommendations relating to internal controls are:

- $\quad$ A full-time manager should be present during all operating hours

- $\quad$ Employees should choose own register password and change password periodically

- University should bond all full-time employees involved in cash handling. 
A test sample for cash transactions is comprised using a judgment sample. The auditors traced sales from the point of origination at the register in the Golden Eagle to the entry in the general ledger at the Bursar's Office. The auditors traced cash transactions to ensure all cash transactions are posted in the general ledger.

Auditors' recommendations relating to cash transactions are:

- $\quad$ Cash should be transferred to the Bursar's office as soon as possible

- $\quad$ University could add a full-time position to handle the cash reporting procedures.

The auditors conducted interviews with management personnel to evaluate inventory procedures. The auditors also inspected inventory reports to determine the adequacy of documentation generated and system relief of inventory.

Auditors' recommendations regarding inventory are:

- Management should document inventory process used

- University needs to invest in an updated, efficient, and effective on-line inventory system.

The auditors discussed the findings and recommendations with Golden Eagle management prior to submitting this written report.

\section{Introduction}

\section{Store Description}

The Golden Eagle is owned and operated by Marquette University. The Golden Eagle Store is located on the ground floor in the Alumni Memorial Union. The store averages an annual sales volume of $\$ 1.5$ million and currently has operating profit totaling $\$ 360,000$. The store provides products for students and alumni including logo clothing, gifts, greeting cards, magazines and some school supplies. The Golden Eagle is open year round and closes for major holidays. The regular store hours are Monday through Friday 9-6, Saturday 10-4 and Sunday 12-4. Summer Store hours are Monday through Friday 9-4:30 and Saturday 10-2. The store is closed weekends during class breaks. The staff consists of four full-time employees: a Director; a Customer Service Coordinator; a Merchandise Coordinator; and an Accounts Coordinator. The staff also consists of twenty-three part-time student employees and two part-time student managers.

\section{Audit Objectives}

- Obtain an Understanding of Internal Controls

A. Determine if the Golden Eagle has a policies and procedures manual to train and provide guidance to their employees.

B. Determine if the policies and procedures are well-defined and formally documented.

C. Decide how aggressively the part-time student employees are supervised.

D. Determine if a full-time employee is in the store during all store hours to oversee the activities of the students, answer any questions a student may have and deal with any circumstances needing management attention.

E. Determine if students are held accountable for their responsibilities, i.e. students required to balance out at the end of each shift.

F. Ensure proper segregation of duties for cash transactions.

- $\quad$ Perform Tests on Cash Transactions

A. Ensure cash is properly handled at the register, documented at the end of shifts, delivered to the Bursar's Office and recorded in the general ledger.

B. Determine that all cash transactions are posted accurately in the general ledger Bursar's Office. 
- $\quad$ Evaluate Inventory Procedures
A. Determine how system relieves inventory.
B. Decide if the inventory system adequately documents the relief of inventory.
C. Determine how the Director decides when to reorder inventory and if this method is clearly documented.

\section{Procedure To Gain An Understanding Of Internal Controls}

The auditors inspected policies and procedures manual. The policies and procedures define the responsibilities of student employees, supervisors and managers. The auditors observed staff activities and compared to the responsibilities documented in the policies and procedures. See workpapers $D^{1-33}$ for a detailed description of the Golden Eagle Policies and Procedures.

\section{Internal Control Testing Procedure}

- Interview the Customer Service Coordinator, to determine understanding of responsibilities is in accordance with policies and procedures established by management. Auditors asked the Customer Service Coordinator the following question to test her understanding:

A. What is your position and what duties does this position require? See workpaper E-1 for response. Agreement found.

- Compare the Customer Service Coordinator's understanding of the cash reporting to ensure agreement with procedure documentation in the policies and procedures manual. Auditors posed the following questions to test the Customer Service Coordinator's understanding:

A. Could you bring us through a cash transaction from step one (merchandise brought to register counter) through step two (receipt printout)? See workpaper E-1 for answer. Agreement found.

B. When is money in the cash register counted? Who counts the money in the drawer? How? Where? See workpaper E-1 for response. Agreement found.

C. What types of reports does the computer or register generate? Who prepares reports? See workpapers E-1 and E-2 for answer. Agreement found.

D. What procedures are taken when there is a discrepancy (over or short)? See workpaper E-2 for response. Agreement found.

E. Observed cash reporting procedure performed by the Customer Service Coordinator and cash recording procedure performed by the Accounts Coordinator to conclude if proper segregation of duties occurs. Agreement found.

- Compare observation of cash reporting procedures performed by Customer Service Coordinator and Accounts Coordinator with interview responses given by Customer Service Coordinator to ensure segregation of duties actually happen. Auditors asked the following question to test segregation of duties:

A. What types of reports does the computer or register generate? Who prepares the reports? See workpapers E-1 and E-2 for answer. Segregation of duties found.

- Observe point-of-sale transactions to ensure student compliance with policies and procedures.

- Observe interaction of Customer Service Coordinator with employees to evaluate supervision.

- Compare observation of controls over system (i.e. passwords, key for register, proper authorization for special transactions such as returns, discounts) with responses given by Customer Service Coordinator to test Customer Service Coordinator's understanding of system procedures and controls. Auditors used the following questions to test Customer Service Coordinator's understanding: 
A. Could you bring us through a cash transaction from step one (merchandise brought to register counter) through step two (receipt printout)? See workpaper E-1 for response. Agreement with observation.

B. Is store credit or cash given for purchase returns? See workpaper E-3 for answer. Agreement with observation.

C. What procedure takes place to return an item? See workpaper E-3 for response. Agreement with observation.

D. Is there a minimum or maximum amount of cash kept in drawer? See workpaper E-3 for answer. Agreement with observation.

E. Besides Hot Keys, are any other controls set in place on the cash register? See workpaper E-3 for response. Agreement with observation.

\begin{tabular}{|c|c|c|}
\hline Problem & Recommendation & Reasoning \\
\hline $\begin{array}{l}\text { Student manager is only present on } \\
\text { weekdays after } 4: 30 \text { p.m. and on } \\
\text { weekends. }\end{array}$ & $\begin{array}{l}\text { Full-time manager should be present during } \\
\text { all operating hours. Additional full-time } \\
\text { manager should be hired. }\end{array}$ & $\begin{array}{l}\text { Full-time managers hired are generally } \\
\text { more responsible and knowledgeable } \\
\text { of retail activities. Hiring an } \\
\text { additional full-time manager would } \\
\text { decrease the risk of theft or } \\
\text { misappropriation of assets. }\end{array}$ \\
\hline $\begin{array}{l}\text { *Cash register password is last four } \\
\text { digits of the employees' social } \\
\text { security number. } \\
\text { *Per discussion with Customer } \\
\text { Service Coordinator on February } \\
28,2002\end{array}$ & $\begin{array}{l}\text { Employees should choose own register } \\
\text { password and change password periodically. }\end{array}$ & $\begin{array}{l}\text { Social security numbers of employees } \\
\text { are available to managers. Managers } \\
\text { could log-in under an employee. In } \\
\text { addition, social security numbers could } \\
\text { mistakenly become available to other } \\
\text { employees allowing the employees to } \\
\text { log-in as another employee. } \\
\text { Determining passwords personally } \\
\text { decreases the risk of false log-ins. }\end{array}$ \\
\hline $\begin{array}{l}\text { *Full-time employees involved in } \\
\text { cash handling are not bonded. } \\
\text { **Determined from conversation } \\
\text { with Director on April } 30,2002 \text {. }\end{array}$ & $\begin{array}{l}\text { The university should bond all full-time } \\
\text { employees involved in cash handling. }\end{array}$ & $\begin{array}{l}\text { Bonding full-time employees with cash } \\
\text { handling duties will protect the } \\
\text { university from cash losses due to } \\
\text { theft. }\end{array}$ \\
\hline
\end{tabular}

\section{Internal Control Findings And Recommendations}

\section{Management Comments on Internal Control}

- The size of the full-time staff and number of operating hours make having a full-time regular staff member present during all store hours not feasible. Student managers are selected based on previous retail management experience with cash handling, store merchandising and inventory responsibilities.

- $\quad$ Student managers work weekdays from 3 PM to 6:30 PM with store supervision responsibility after 4:30 PM. Student managers receive direction from full-time staff members prior to 4:30 PM. Student managers are fully trained in-store and participate in the student manager-training program once a week in the AMU.

- Passwords - having students select their own unique password is an excellent suggestion. This will be implemented after 6/1/02.

- $\quad$ Management will pursue the bonding issue with Internal Audit and Public Safety in FY 2003.

Note: Apparently neither the staff at Golden Eagle nor the students were aware that the Office of Risk Management procures fidelity bonds on behalf of the University covering its employees as well as provides other financial insurance instruments for theft of cash and securities as part of the Risk Management and Insurance Program. The master program negates the need for individual bonds on full-time Golden Eagle employees. 


\section{Cash Transaction Testing Procedure}

\begin{tabular}{|c|c|c|c|c|c|}
\hline \multirow{2}{*}{$\begin{array}{l}\text { Corresponding } \\
\text { step in work } \\
\text { papers } \\
\end{array}$} & \multirow[t]{2}{*}{ Procedure } & \multicolumn{3}{|c|}{ Results } & \multirow[t]{2}{*}{ Deficiencies } \\
\hline & & $2 / 1 / 2002$ & $2 / 6 / 2002$ & 2/8/2002 & \\
\hline Step 3 & $\begin{array}{l}\text { Match total dollar sales on shift summaries } \\
\text { to dollar sales on sales and receipts } \\
\text { summary(S\&R summary) }\end{array}$ & $\begin{array}{c}\text { noted } \\
\text { agreement }\end{array}$ & $\begin{array}{c}\text { noted } \\
\text { agreement }\end{array}$ & $\begin{array}{c}\text { noted } \\
\text { agreement }\end{array}$ & none \\
\hline Step 4 & $\begin{array}{l}\text { Verify that total dollar sales on S\&R } \\
\text { summary matches total dollar sales on poll } \\
\text { report }\end{array}$ & $\begin{array}{c}\text { noted } \\
\text { agreement }\end{array}$ & $\begin{array}{c}\text { noted } \\
\text { agreement }\end{array}$ & $\begin{array}{c}\text { noted } \\
\text { agreement }\end{array}$ & none \\
\hline Step 5 & $\begin{array}{l}\text { Tie cash from drawer breakdown to cash on } \\
\text { poll report }\end{array}$ & $\begin{array}{c}\text { noted } \\
\text { agreement }\end{array}$ & $\begin{array}{c}\text { noted } \\
\text { agreement }\end{array}$ & $\begin{array}{c}\text { noted } \\
\text { agreement }\end{array}$ & none \\
\hline Step 6 & $\begin{array}{l}\text { Verify mathematical accuracy of shift } \\
\text { summaries and S\&R summary }\end{array}$ & noted accuracy & noted accuracy & noted accuracy & none \\
\hline Step 6 & $\begin{array}{l}\text { Compare total net sales on shift summaries } \\
\text { to total net sales on S\&R summary }\end{array}$ & \begin{tabular}{|c|} 
noted \\
agreement
\end{tabular} & \begin{tabular}{|c|c|}
$\begin{array}{c}\text { noted } \\
\text { agreement }\end{array}$ \\
\end{tabular} & \begin{tabular}{c|} 
noted \\
agreement
\end{tabular} & none \\
\hline Step 7 & $\begin{array}{l}\text { Verify mathematical accuracy of each } \\
\text { department total and of total sales on poll } \\
\text { report }\end{array}$ & noted accuracy & noted accuracy $\mathrm{r}$ & noted accuracy & none \\
\hline Step 7 & $\begin{array}{l}\text { Match total sales on poll report to total sales } \\
\text { on S\&R summary }\end{array}$ & $\begin{array}{c}\text { noted } \\
\text { agreement }\end{array}$ & \begin{tabular}{c|c} 
noted \\
agreement
\end{tabular} & $\begin{array}{c}\text { noted } \\
\text { agreement }\end{array}$ & none \\
\hline Step 8 & $\begin{array}{l}\text { Verify mathematical accuracy of cash and } \\
\text { check amounts on shift summaries }\end{array}$ & noted accuracy & noted accuracy $\mathrm{n}$ & noted accuracy & none \\
\hline Step 8 & $\begin{array}{l}\text { Tie check and cash amounts to } \mathrm{S} \& \mathrm{R} \\
\text { summary }\end{array}$ & \begin{tabular}{|c|} 
noted \\
agreement \\
\end{tabular} & \begin{tabular}{|c|c|}
$\begin{array}{c}\text { noted } \\
\text { agreement }\end{array}$ \\
\end{tabular} & \begin{tabular}{c|c|} 
noted \\
agreement
\end{tabular} & none \\
\hline Step 9 & $\begin{array}{l}\text { Verify mathematical accuracy of all media } \\
\text { on S\&R summary }\end{array}$ & noted accuracy & noted accuracy $\mathrm{r}$ & noted accuracy & none \\
\hline Step 9 & $\begin{array}{l}\text { Tie total media on S\&R summary to total } \\
\text { tendered on poll report }\end{array}$ & \begin{tabular}{|c|} 
noted \\
agreement
\end{tabular} & \begin{tabular}{c|c|} 
noted \\
agreement
\end{tabular} & \begin{tabular}{c|c} 
noted \\
agreement
\end{tabular} & none \\
\hline Step 10 & $\begin{array}{l}\text { Compare total tendered for all registers on } \\
\text { poll report to daily sales report (DSR) }\end{array}$ & $\begin{array}{c}\text { noted } \\
\text { agreement }\end{array}$ & $\begin{array}{c}\text { noted } \\
\text { agreement }\end{array}$ & $\begin{array}{c}\text { noted } \\
\text { agreement }\end{array}$ & none \\
\hline Step 10 & $\begin{array}{l}\text { Tie all adjustments on daily sales report to } \\
\text { poll report }\end{array}$ & $\begin{array}{c}\text { noted } \\
\text { agreement }\end{array}$ & $\begin{array}{c}\text { noted } \\
\text { agreement }\end{array}$ & $\begin{array}{c}\text { noted } \\
\text { agreement }\end{array}$ & none \\
\hline Step 11 & $\begin{array}{l}\text { Verify mathematical accuracy of net cash } \\
\text { sales on DSR }\end{array}$ & noted accuracy & noted accuracy & noted accuracy & none \\
\hline Step 11 & $\begin{array}{l}\text { Match net cash sales on DSR to cash sales on } \\
\text { cash receipts voucher(CRV) }\end{array}$ & \begin{tabular}{c|c|} 
noted \\
agreement
\end{tabular} & noted agreement & \begin{tabular}{|c|}
$\begin{array}{c}\text { noted } \\
\text { agreement }\end{array}$ \\
\end{tabular} & none \\
\hline Step 12 & $\begin{array}{l}\text { Trace total checks and cash from CRV to } \\
\text { media log and deposit book }\end{array}$ & $\begin{array}{c}\text { noted } \\
\text { agreement }\end{array}$ & noted agreement & $\begin{array}{c}\text { noted } \\
\text { agreement }\end{array}$ & none \\
\hline Step 13 & $\begin{array}{l}\text { Trace total from CRV to deposit log at } \\
\text { Bursar's office }\end{array}$ & $*$ & + & \# & $\begin{array}{l}\text { cash amounts } \\
\text { were not } \\
\text { deposited daily } \\
\text { at the Bursar's } \\
\text { office }\end{array}$ \\
\hline Step 14 & $\begin{array}{l}\text { Trace total deposit to Bursar daily cash } \\
\text { report }\end{array}$ & $\begin{array}{c}\text { noted } \\
\text { agreement }\end{array}$ & noted agreement & \begin{tabular}{c|c} 
noted \\
agreement
\end{tabular} & none \\
\hline $\begin{array}{l}* \text { Auditors were } \\
\text { amount of } \$ 1875 \\
\text { then traced to the } \\
+ \text { The amount o } \\
\text { log at the Bursar' } \\
\# \quad \text { The amount } \\
\text { traced to the dep }\end{array}$ & $\begin{array}{l}\text { nable to trace amounts on individual cash recei } \\
0 \text { for } 2 / 1 \text { was totaled with the amounts for } 2 / 2 \\
\text { eposit log at the Bursar's office. } \\
\$ 811.73 \text { from } 2 / 6 \text { was totaled with the amount } \\
\text { ffice. } \\
\$ 1179.81 \text { from } 2 / 8 \text { was totaled with the amol }\end{array}$ & $\begin{array}{l}\text { ts vouchers dire } \\
2 / 3,2 / 4 \text {, and } 2 / 5 \text {. } \\
\text { om } 2 / 7 \text {. The tot } \\
\text { ats from } 2 / 9,2 / 1\end{array}$ & $\begin{array}{l}\text { The total } \$ 17,60 \\
\text { tal of } \$ 1849.13 \text { we } \\
0 \text {, and } 2 / 11 \text {. The }\end{array}$ & $\begin{array}{l}\text { gat the Bursar's } \\
605.13 \text { for the fi } \\
\text { vas then traced to } \\
\text { total of } \$ 5582 \text {. }\end{array}$ & $\begin{array}{l}\text { s office. The } \\
\text { ive days was } \\
\text { to the deposit } \\
.04 \text { was then }\end{array}$ \\
\hline
\end{tabular}


The auditors examined sales transactions for three days in the month of February 2002. The auditors used a judgment sampling method to choose two Fridays, 2/1/02 and 2/8/02, and one Wednesday, 2/6/02. The auditors chose this selection in order to compare days with both high sales volume and lower sales volume. Fridays are generally high sales volume days at the Golden Eagle and Wednesdays are generally lower sales volume days. They desired this mix in order to ensure consistency in transaction processing for both high and low sales volume days. The auditor traced sales from the point of origination at the register in the Golden Eagle to the entry in the general ledger at the Bursar's Office. See workpaper E-6 for a detailed description of the procedures performed.

\section{Cash Transaction Findings And Recommendations}

\begin{tabular}{|c|c|c|}
\hline Problem & Recommendation & Reasoning \\
\hline $\begin{array}{l}\text { Cash is held in the store safe for more than } \\
\text { one day. This is due to the multiple } \\
\text { responsibilities held by Customer Service } \\
\text { Coordinator. Customer Service Coordinator } \\
\text { is often unable to complete her cash } \\
\text { reporting responsibilities daily because she is } \\
\text { busy training employees, organizing work } \\
\text { schedules and performing other } \\
\text { responsibilities as the Customer Service } \\
\text { Coordinator. During the testing procedure it } \\
\text { was found that cash and checks taken in on } \\
\text { February } 1,2002 \text { were not picked up by the } \\
\text { Bursar's Office until February } 6,2002 \text { (see } \\
\text { workpaper C-28). Other dates tested were } \\
\text { found to be similar. }\end{array}$ & $\begin{array}{l}\text { Cash should be transferred to the } \\
\text { Bursar's office as soon as possible. } \\
\text { The university could add a full-time } \\
\text { position to handle the cash } \\
\text { reporting procedures. }\end{array}$ & $\begin{array}{l}\text { Allowing cash to remain in the store } \\
\text { for more than one day increases the } \\
\text { risk of theft. Cash should be } \\
\text { transferred as often as possible to } \\
\text { reduce this risk. Adding another } \\
\text { full-time employee would eliminate } \\
\text { the inability to transfer cash daily. } \\
\text { The additional employee would also } \\
\text { allow Customer Service Coordinator } \\
\text { to focus her time on her customer } \\
\text { service coordinator responsibilities. }\end{array}$ \\
\hline
\end{tabular}

\section{Management Comments on Cash Transactions}

- $\quad$ Cash is stored in a secure drop safe including cash from more than one business day. Secure drop safe has extremely limited access. Only the Director and Customer Service Coordinator have access to the safe.

- Adding an additional employee, while a welcome suggestion, is not feasible at this time. University budget restrictions make this impossible.

- Cash reporting is an extremely important part of the duties performed by the Customer Service Coordinator and takes priority over all other projects other than customer service issues. Deposits are made into the Bursar's Office in the timeliest fashion currently possible.

\section{Inventory Testing Procedure}

- Interview with the Director about inventory system to determine how inventory is relieved and the method used to reorder inventory. Auditors asked the following questions to the Director to evaluate relief of inventory:
A. When you sell one item, can that be shown in the system? See the attachment for response.
B. How do you determine when to reorder inventory? See the attachment for response.
C. How do you determine how much to reorder? See the attachment for response.

- Inspect daily product sales report to determine if relief of inventory is adequately documented in the system. 


\section{Inventory Findings and Recommendations}

\begin{tabular}{|l|l|l|}
\hline \multicolumn{1}{|c|}{ Problem } & \multicolumn{1}{|c|}{ Recommendation } & \multicolumn{1}{c|}{ Reasoning } \\
\hline $\begin{array}{l}\text { No formal documentation regarding the Director's } \\
\text { duties involving inventory. }\end{array}$ & $\begin{array}{l}\text { Inventory process the } \\
\text { Director uses should be } \\
\text { documented. }\end{array}$ & $\begin{array}{l}\text { Documentation will be needed for } \\
\text { another employee to perform the } \\
\text { Director's duties if he became sick } \\
\text { for extended period of time, } \\
\text { an an extended vacation, or were } \\
\text { to } \\
\text { resign or be dismissed from } \\
\text { position. }\end{array}$ \\
\hline $\begin{array}{l}\text { System does not generate reports that adequately show } \\
\text { relief of inventory. When sale of an individual } \\
\text { product occurs it is recorded in the register and } \\
\text { becomes part of a department total. The department } \\
\text { total can only be broken down to the extent of daily } \\
\text { total sales by product number. }\end{array}$ & $\begin{array}{l}\text { University needs to invest in } \\
\text { an updated, efficient, and } \\
\text { effective on-line inventory } \\
\text { system. }\end{array}$ & $\begin{array}{l}\text { Comparability of inventory records } \\
\text { will improve. Actual sales and on- } \\
\text { hand quantities of inventory will } \\
\text { reconcile. }\end{array}$ \\
\hline
\end{tabular}

\section{Management Comments on Inventory System}

- Management of inventory, while performed in a methodical manner, is subjective and requires creativity. Written instructions are somewhat difficult to develop but will be addressed in Fiscal 2003. Replacement for current Director requires 5-10 years of retail management and purchasing experience.

- New internal inventory and point-of-sale system is slated for Fiscal 2003. Though the current system may have auditing deficiencies, it serves the internal point-of-sale and management operations well.

\section{EXHIBIT 5}

$\begin{array}{ll}\text { Date } & \text { Activity } \\ 2 / 25 & \text { Initial meeting } \\ 2 / 25 & \text { Prepare questionnaire } \\ 2 / 27 & \text { Interview with auditee } \\ 2 / 28 & \text { Observe cash reporting procedure } \\ 2 / 28 & \text { Interview with auditee } \\ 2 / 28 & \text { Meeting with outside consultant } \\ 3 / 3 & \text { Document interview with auditee } \\ 3 / 5 & \text { Determine transaction testing procedure to be used } \\ 3 / 19 & \text { Make copies of all transactions to be tested } \\ 4 / 7 & \text { Test transactions } \\ 4 / 9 & \text { Meeting with outside consultant } \\ 4 / 14 & \text { Begin writing audit report } \\ 4 / 16 & \text { Write transaction testing procedure } \\ 4 / 17 & \text { Meet with Bursar's Office } \\ 4 / 18 & \text { Write audit report } \\ 4 / 21 & \text { Work on revisions } \\ 4 / 26 & \text { Meet with professor about revisions } \\ 4 / 30 & \text { Meet with auditee } \\ 4 / 30 & \text { Rewrite audit report } \\ 5 / 1 & \text { Complete audit report draft } \\ 5 / 2 & \text { Exit interview with Golden Eagle management } \\ 5 / 2 & \text { Final write-up of audit report } \\ & \text { Total hours - Student auditor 1 } \\ & \text { Total hours - Student auditor 2 } \\ & \end{array}$

Hours Performed By

$\begin{array}{ll}0.5 & 1 / 2\end{array}$

$1.5 \quad 1 / 2$

$2.0 \quad 1 / 2$

$1.5 \quad 1$

$0.5 \quad 1$

$0.5 \quad 1 / 2$

1.52

$2.0 \quad 1 / 2$

$2.0 \quad 1 / 2$

$4.0 \quad 1 / 2$

$0.5 \quad 1 / 2$

$1.0 \quad 1 / 2$

$2.0 \quad 1$

$2.0 \quad 2$

$3.0 \quad 1 / 2$

$3.0 \quad 1$

$1.0 \quad 1$

$0.8 \quad 1 / 2$

$3.0 \quad 1 / 2$

$4.5 \quad 1 / 2$

$0.5 \quad 1 / 2$

$1.5 \quad 1 / 2$

35.3

30.8 


\section{EXHIBIT 6}

\section{Excerpt Of Marquette University's Audit Course Syllabus}

\section{Course Policies}

Grading

Exams, 3 @150

Comprehensive Final

Case Analyses, 2 @ 50

Audit Case

Video Review

$\begin{array}{rr}450 \text { points } & 50 \% \\ 190 \text { points } & 21 \% \\ 100 \text { points } & 11 \% \\ 145 \text { points } & 16 \% \\ 15 \text { points } & 2 \%\end{array}$

Totals

900 points

$100 \%$

Audit for Internal Audit Department

Each graduate student is required to complete an operational audit for the internal audit department in addition to the other course requirements. A consultant working with the internal audit department will supervise this engagement. The entire audit (from planning to reporting) will take approximately 25 hours.

\section{NOTES}


NOTES 